\title{
Problems of regeneration of modern piezoelectric fuel injectors
}

\section{ARTICLE INFO}

Received: 10 January 2022 Revised: 13 February 2022

Accepted: 14 February 2022

Available online: 5 March 2022
The paper presents a method of testing piezoelectric fuel injectors in modern common rail systems, which allows them to be repaired almost to the full extent. The obtained results indicate that this process can be effectively carried out, even taking into account the existing technological limitations. The most important stages of the implemented activities are specified, first of all the scope of required maintenance activities in the preand post-assembly stages, as well as the types of diagnostic tests carried out on separate test benches. Although the presented analysis concerns a specific example, individual conclusions and observations can be applied to fuel injectors from other manufacturers, in which the actuator is not replaceable.

Key words: common rail system, piezoelectric fuel injector, diagnostic tests, regeneration process

This is an open access article under the CC BY license (http://creativecommons.org/licenses/BY/4.0/)

\section{Introduction}

There is an increased demand for the regeneration of piezoelectric fuel injectors on the market of maintenance services. Although this technology does not play a dominant role in modern common rail systems, in which solutions with a solenoid operated valve predominate, the percentage of its use is systematically growing $[1,19]$. This is due to the optimal shaping of the high-pressure direct fuel injection strategy, implemented with a highly flexible and multiple division of the dosed fuel during a single diesel engine cycle. This is essential from the point of view of reducing fuel consumption as well as reducing noise emissions and the toxicity of exhaust fumes [13, 21, 22]. Due to the above considerations, piezoelectric fuel injectors are offered by all major manufacturers of fuel injection equipment. Moreover, the increasing access to spare parts as well as specialized accessories and diagnostic devices significantly increased their repair possibilities.

At present, the most important problem is the issue of the crystal stack, usually placed inside the main body, which effectively eliminates its replacement, e.g. Bosch, Denso, Delphi [4, 6, 18]. The exception to this rule is the products of Siemens VDO Continental, which is a world leader in the field of PCR (Piezo Common Rail) systems, in which the actuator is screwed to the upper part of the fuel injector with a nut. As a result, disassembly of this element is not difficult, as it is similar to the use of a classic solenoid $[5,26]$. In other cases, it is possible to revitalize the stack, i.e. remove micro-short circuits between individual layers by means of a current signal of a specific amplitude. However, this process has no effect on mechanical damage, and additionally it must be carried out on specially dedicated test benches, e.g. DS2R, CRU2r, CRU4R [24]. The high precision of individual actuators makes them the most susceptible to damage components of common rail systems in difficult operating conditions.

The tests were mainly aimed at assessing the possibility of repairing the third generation piezoelectric fuel injector, taking into account and using cognitive techniques that will enable its full efficiency to be restored. For this reason, a range of maintenance and repair activities was proposed, implemented at individual stages of this process, taking into account the difficulties and technological limitations. The methodology is distinguished by the use of equipment that is not used in the manufacturer's standard procedures.

\section{Methods}

\subsection{Test object}

The tests were carried out on a Bosch CRI3-16 piezoelectric fuel injector, which was removed from the 3.0 TDI (Turbo Direct Injection) engine of a Volkswagen Touareg passenger car with an operational mileage of 262 thousand $\mathrm{km}$.

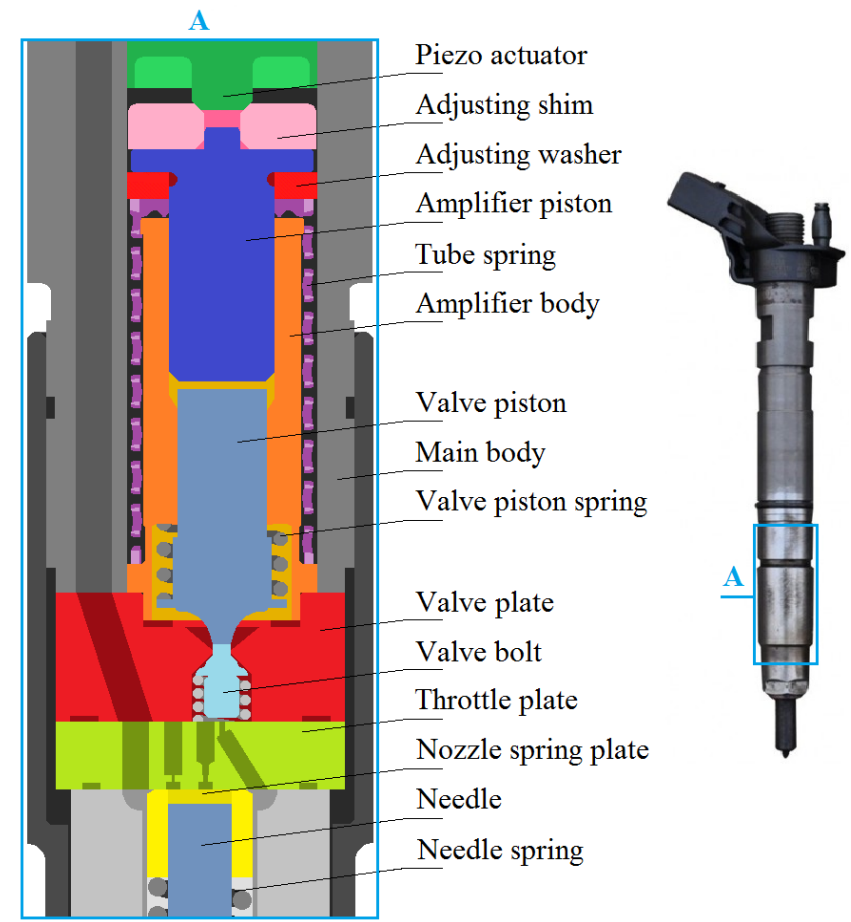

Fig. 1. Bosch CRI3-16 fuel injector design: own study based on [20]

This type of fuel injector belongs to the third generation CRS3 (Common Rail System) systems, operating at work- 
ing pressure up to $160 \mathrm{MPa}$ [9]. Figure 1 shows the most important elements of the internal structure, specifying the control valve assembly and the hydraulic amplifier. Other characteristic features include the triangular cross-section of the needle in the guiding part, providing space for free fuel flow. Moreover, compared to solenoid solutions, the high pressure feed connector is positioned centrally rather than laterally, which simplifies the upper part of the main body. For this reason, the overflow connector is located next to the flange with the electrical connection [12].

\subsection{Test beds}

During the regeneration of the fuel injector, the following apparatus and dedicated instrumentation were used, which included:

- 12PSB test bench with a complete Stardex kit (Fig. 2),

- Mega Tester V3 piezoelectric actuator tester,

- Bass BP-3605 fuel injector pressure tester,

- Yizhan 13MP HDMI VGA microscope camera,

- Polsonic Sonic 9, Bene YesWeCan 3L ultrasonic cleaners,

- IP54 electronic micrometer,

- Facom E.316A200S electric torque wrench,

- GRS Tools POWER HONE diamond grinder,

- vices, grips and workshop tools.

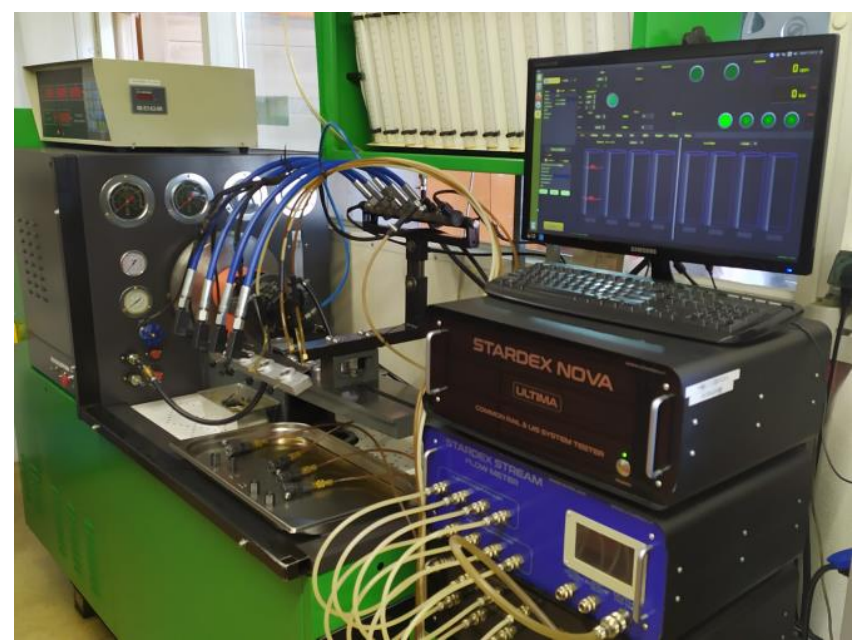

Fig. 2. 12PSB test bench with Stardex kit

\subsection{Research plan}

Figure 3 shows an in-house test plan which only partially overlaps with Bosch's procedures. Due to the available equipment, checking the piezoelectric actuator and the state of tightness can be carried out in the initial stages. The detection of a failure results in the suspension of the regeneration process or the exclusion of the fuel injector from thermochemical cleaning and preliminary flow measurements on the test bench. In addition, washing in ultrasonic baths takes place after microscopic inspection and applies only to those components that will not be replaced. Differences may also apply to the correction of fuel dosage, as the manufacturer assumes top-down adjustment by means of coding or by earlier disassembly of the nozzle and changing the thickness of the needle washer (not shown in Fig. 1). The latter method results from the frictional wear of the plunger and barrel assembly, which is one of the most fre- quently detected failures in common rail fuel injectors $[2,3$, 8]. However, this process can be extended in the situations when other irregularities are found during the tests.

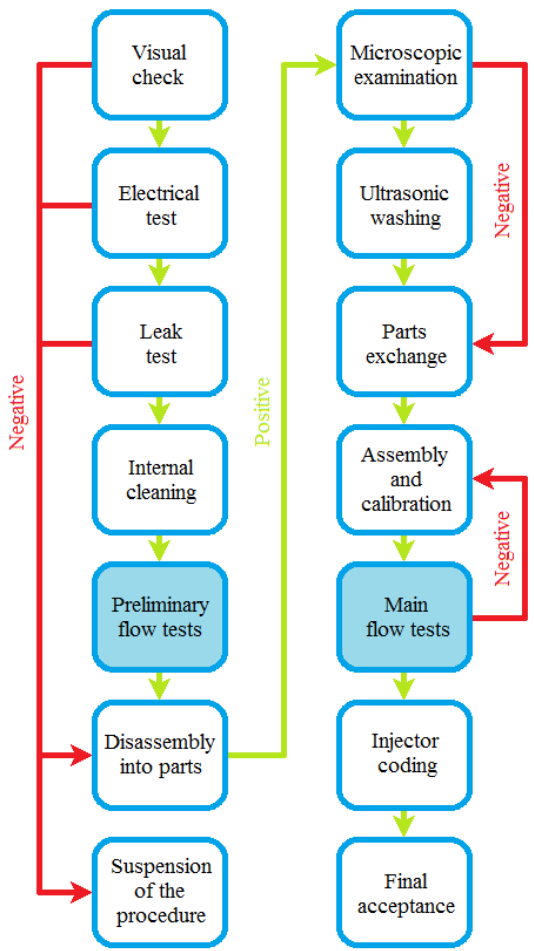

Fig. 3. Research plan

\section{Analysis results and discussion}

\subsection{Preliminary tests}

The inspection of the tested fuel injector did not reveal any external defects or incompleteness of its components. Therefore, electrical measurements were performed using the Mega Tester V3 (Fig. 4). The data presented in Table 1 show that the piezoelectric actuator was functional, as the values of all parameters were within the nominal ranges. The main difference compared to Siemens VDO Continental products is the lack of necessity to control GAP, i.e. the size of the gap between the crystal stack and the hydraulic valve lifter [15].

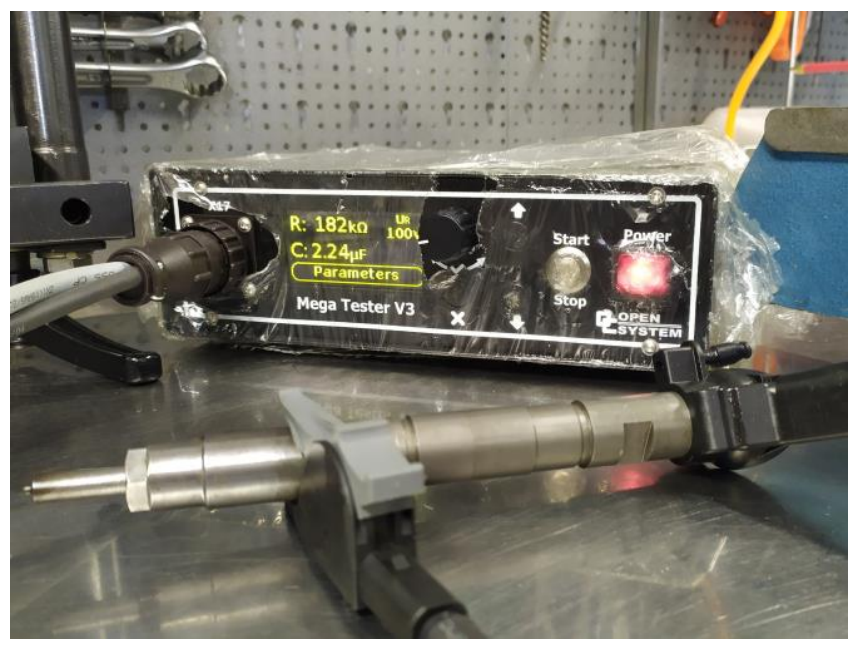

Fig. 4. Testing piezoelectric actuator with the Mega Tester V3 
Table 1. Results of the electric tests

\begin{tabular}{|l|c|c|}
\hline \multicolumn{1}{|c|}{ Type of parameter } & $\begin{array}{c}\text { Nominal } \\
\text { range }\end{array}$ & Result \\
\hline Piezo actuator resistance, $\mathrm{R}[\mathrm{k} \Omega]$ & $150-210$ & 182 \\
\hline Piezo actuator initial capacitance, $\mathrm{C}[\mu \mathrm{F}]$ & $1.5-3.3$ & 2.24 \\
\hline Continuous resistance test, $\mathrm{R}_{\mathrm{C}}[\mathrm{k} \Omega]$ & $150-210$ & $182-183$ \\
\hline Piezo actuator insulation resistance, $\mathrm{R}_{\mathrm{I}}[\mathrm{M} \Omega]$ & $10-\infty$ & $\infty$ \\
\hline
\end{tabular}

In the next step, the tightness of the fuel injector was checked on the Bass BP-3605 tester (Fig. 5). At a pressure of $40-50 \mathrm{MPa}$, no leaks were found in the area of the nozzle and the overflow connector. This proves that the nozzle and the nut are kept tight, as well as the valve assembly. At this stage, it is possible to test the quality of fuel atomisation, but it is necessary to provide a control impulse from an additional diagnostic device, e.g. AZ0222-CRR, SRN.101.540, AZ0134-13. This test is carried out optionally, mainly in the case of suspected obstruction of the exit holes, changes in their geometry, bad condition of the tip, etc.

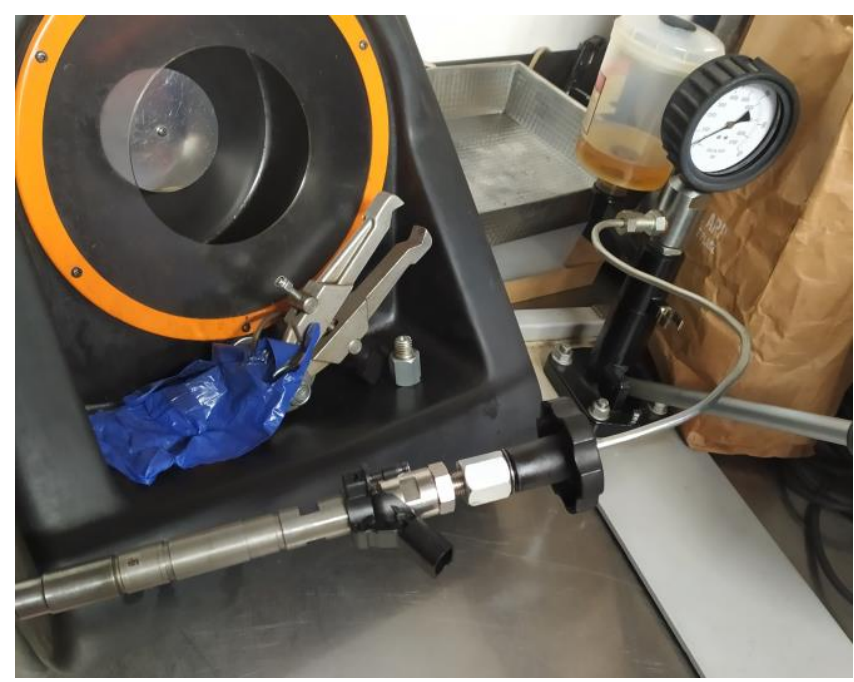

Fig. 5. The fuel injector leak test on the Bass BP-3605 tester

In accordance with the adopted test plan, the CRI3-16 fuel injector was subjected to thermochemical cleaning. In this process, as in the preliminary flow measurements, a 12PSB test bench with a Stardex kit was used (Fig. 6).

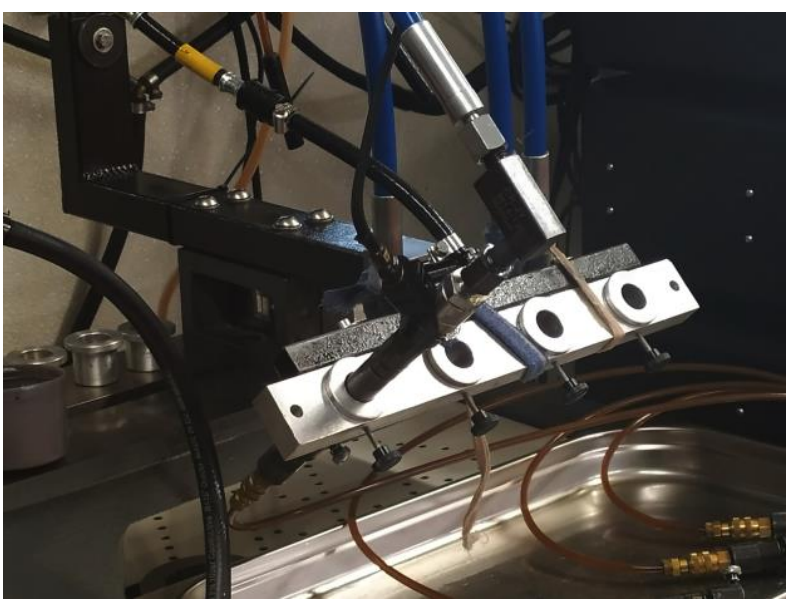

Fig. 6. View of the fuel injector during flow measurements
The results presented in Table 2 show that a negative result of the measurements was obtained at full load. A disturbance in the fuel supply after the maximum pressure and control time have been set, may suggest a problem in the operation of the actuator group. Despite the fact that the criteria specified by the manufacturer were met for the remaining operating points, the values of fuel injection doses also seem to be slightly underestimated. It would be premature to indicate possible causes, at least until the fuel injector is disassembled and the individual components are inspected. Nevertheless, improper cooperation of the plunger and barrel assembly should be ruled out, as wearing of the needle in the nozzle would be visible in the idle and pre-injection tests $[10,25]$.

Table 2. Results of the preliminary fuel injector flow test

\begin{tabular}{|l|c|c|c|c|}
\hline \multirow{2}{*}{$\begin{array}{c}\text { Test } \\
\text { name }\end{array}$} & \multirow{2}{*}{$\begin{array}{c}\text { Injection } \\
\text { pressure, }\end{array}$} & \multirow{2}{*}{$\begin{array}{c}\text { Nozzle } \\
\text { opening } \\
\text { times, } \\
\mathrm{p}_{\text {inj }}[\mathrm{MPa}]\end{array}$} & \multicolumn{2}{|c|}{$\begin{array}{c}\text { Injection dosage, } \\
\mathrm{d}[\mathrm{ml} / \mathrm{min}]\end{array}$} \\
\cline { 4 - 5 } & $\mathrm{t}[\mu \mathrm{s}]$ & $\begin{array}{c}\text { Nominal } \\
\text { range }\end{array}$ & Result \\
\hline Maximum Load & 160 & 550 & $46.2 \pm 6.5$ & 39.4 \\
\hline Emission Point & 80 & 465 & $18.7 \pm 4.3$ & 18.0 \\
\hline Pre-injection & 120 & 170 & $1.8 \pm 1.5$ & 1.2 \\
\hline Idle & 25 & 525 & $3.1 \pm 2.7$ & 3.1 \\
\hline
\end{tabular}

In organoleptic tests and under high microscopic magnification, corrosion centres were revealed on parts that were in direct contact with the fuel, e.g. on the throttle and valve plates (Fig. 7a). Traces of frictional wear were also observed on some working surfaces, in particular on those from the hydraulic booster (Fig. 7b). As a result, it was decided that the the above actuator assemblies would be replaced completely. Moreover, taking into account the operational mileage over $200,000 \mathrm{~km}$, a new nozzle was used, similarly to the regeneration of fuel injectors from other manufacturers [23]. It should be emphasised, however, that the technical condition of the needle and the nozzle did not raise any major objections (Fig. 8). The remaining components were bathed in ultrasonic cleaners and then thoroughly dried with compressed air.

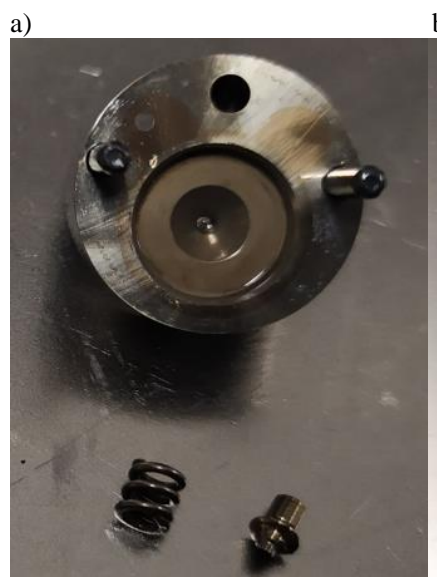

b)

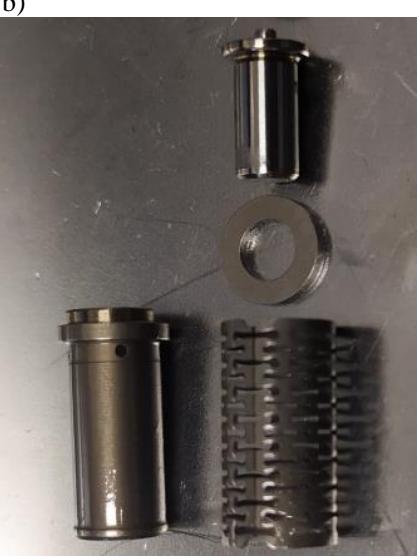

Fig. 7. Exemplary parts of the valve group a) amplifier module b)

The data presented in the literature show that the properties of piezoelectric crystals deteriorate with long-term operation [7, 16, 17]. As a result of the ageing process, the response to the electric impulse changes, thus reducing the 
elongation of the actuator and the impact on the moving parts of the injector [14]. This means that the actions taken may turn out to be insufficient, because even with the valve replaced, an increased amount of fuel will be transferred to the overflow.

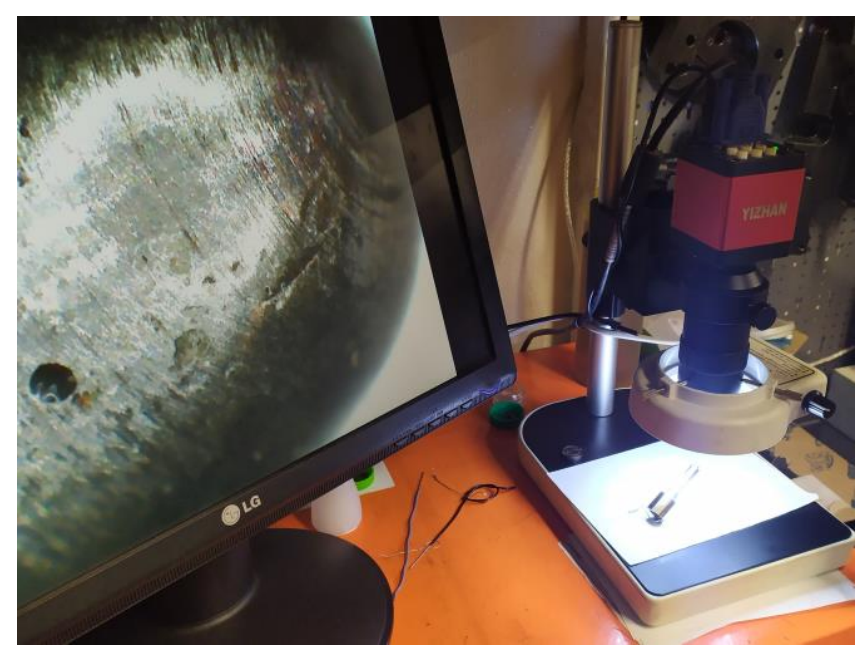

Fig. 8. Microscopic inspection of the nozzle tip

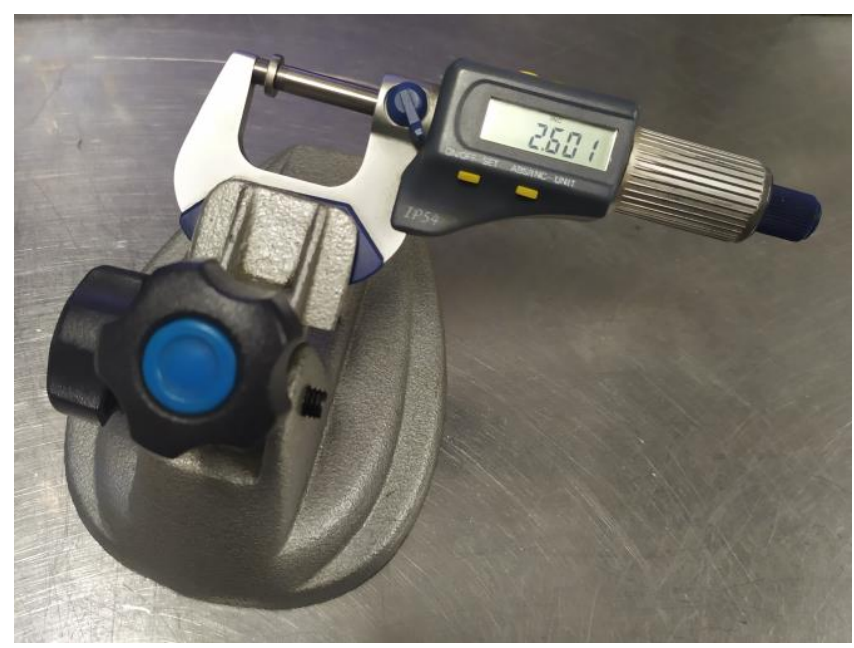

Fig. 9. Measurement of the adjusting shim thickness after grinding

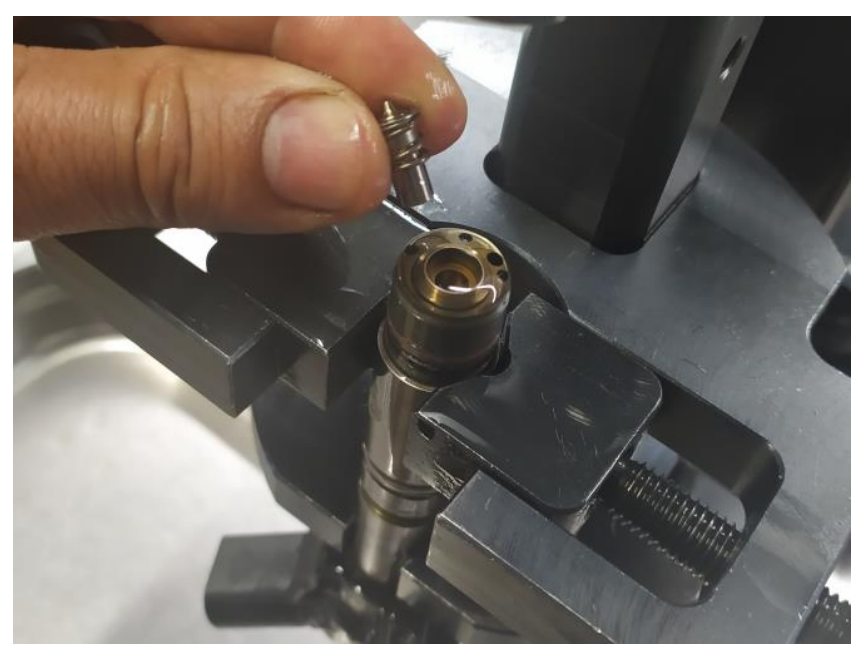

Fig. 10. Assembly of the hydraulic booster
Taking into account the results of preliminary tests, it was decided that the stack length compensation would be ensured by grinding the front surface of the adjusting shim of the hydraulic booster by $0.2 \mathrm{~mm}$ (Fig. 9). In turn, the assembly of this assembly required venting and pressing in the presence of oil (Fig. 10 and 11). In this way, falsification of the measurements on the test bench, i.e. the occurrence of the so-called zero doses, is prevented.

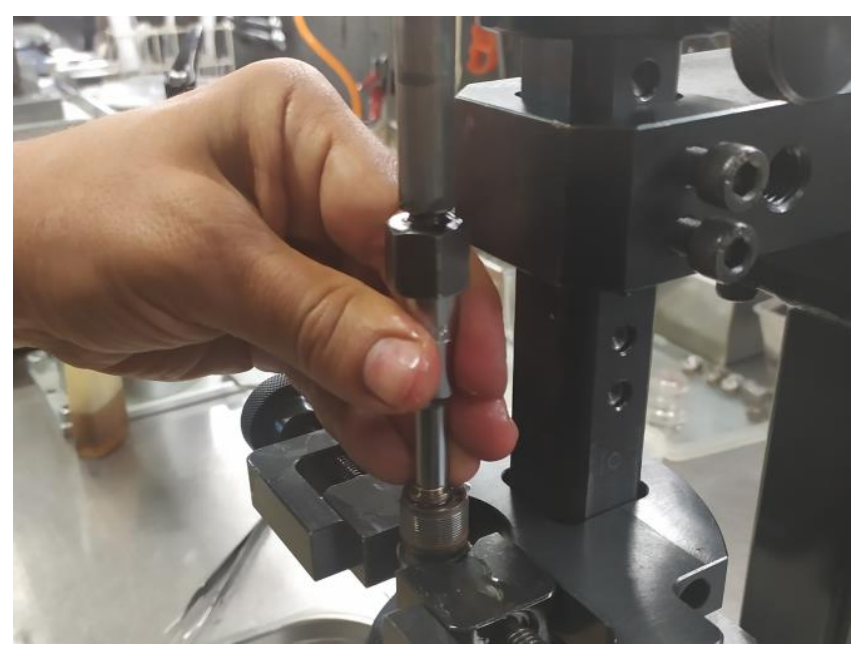

Fig. 11. Pressing step in the presence of oil

\subsection{Main tests}

Table 3 shows the results of the main tests that were carried out after the fuel injector was regenerated. This process should be assessed positively, as the fuel injection doses within the required limits were obtained at all operating points. Moreover, their values were increased compared to the initial state, which proves that the damage was correctly verified and the actions taken were right.

Table 3. Results of the main fuel injector flow test

\begin{tabular}{|l|c|c|c|c|}
\hline \multirow{2}{*}{$\begin{array}{c}\text { Test } \\
\text { name }\end{array}$} & \multirow{2}{*}{$\begin{array}{c}\text { Injection } \\
\text { pressure, }\end{array}$} & \multirow{2}{*}{$\begin{array}{c}\text { Nozzle } \\
\text { opening } \\
\text { times, } \\
\text { p }\end{array}$} & \multicolumn{2}{|c|}{$\begin{array}{c}\text { Injection dosage, } \\
\mathrm{d}[\mathrm{ml} / \mathrm{min}]\end{array}$} \\
\cline { 4 - 5 } & $\mathrm{p}[\mu \mathrm{s}]$ & $\begin{array}{c}\text { Nominal } \\
\text { range }\end{array}$ & Result \\
\hline Maximum load & 160 & 550 & $46.2 \pm 6.5$ & 43.2 \\
\hline Emission point & 80 & 465 & $18.7 \pm 4.3$ & 19.4 \\
\hline Pre-injection & 120 & 170 & $1.8 \pm 1.5$ & 1.6 \\
\hline Idle & 25 & 525 & $3.1 \pm 2.7$ & 4.2 \\
\hline
\end{tabular}

It is also worth noting that in some cases, compensation for the loss resulting from the ageing of the crystal stack may be limited only to assigning a new ISA (German: Injektor-Spannungs-Abgleich) code. It consists in finding a higher threshold voltage at which the actuator will open the valve through the hydraulic booster assembly and raise the needle in the nozzle. As a result, coding the piezoelectric fuel injector, i.e. shifting its operation range, becomes a kind of corrective action [11], supplementing the information on the correction of fuel dosage IMA (German: Injektor-Mengen-Abgleich). The procedure is carried out automatically on the same diagnostic stand that was used in flow tests. 


\section{Conclusions}

The proposed method allows the regeneration of common rail piezoelectric fuel injectors, as shown in a specific example. Due to the extended scope of maintenance and diagnostics, as well as easier access to spare parts, this process is not limited only to the stages of cleaning, testing and assigning new codes. This also applies to the replacement of the plunger and barrel assembly for selected reference numbers, treated in recent years as the first and, in principle, the only stage of repair. Of course, the necessary condition for the effectiveness of the activities carried out is the technical condition of the actuator itself, which, unlike other control and actuator elements, is still not replaceable.
By making this technology available on the market of maintenance services market, the repair will be completely full-spectrum, as is the case with Siemens VDO Continental products.

\section{Acknowledgements}

The paper was created thanks to the cooperation with AUTO NEXT SERWIS car service company based in Szczecin (Prawobrzeże Quarter), which provided test benches, apparatus and accessories used in the regeneration process of the tested fuel injector.

\section{Nomenclature}

$\begin{array}{llll}\mathrm{C} & \text { piezo actuator initial capacitance } & \text { ISA } & \text { injector voltage correction } \\ \mathrm{CRI} & \text { common rail injector } & \mathrm{PCR} & \text { piezo common rail system } \\ \mathrm{CRS} & \text { common rail system } & \mathrm{p}_{\mathrm{inj}} & \text { injection pressure } \\ \mathrm{d} & \text { injection dosage } & \mathrm{R} & \text { piezo actuator resistance } \\ \mathrm{GAP} & \text { space between the piezo actuator and the injector } & \mathrm{R}_{\mathrm{C}} & \text { continuous resistance test } \\ & \text { hydraulic valve pusher } & \mathrm{R}_{\mathrm{I}} & \text { piezo actuator insulation resistance } \\ \mathrm{IMA} & \text { correction of injector doses } & \mathrm{t} & \text { nozzle opening times }\end{array}$

\section{Bibliography}

[1] AMbrosio, S., FERrARI, A., MANCARELlA, A. at al. Comparison of the emissions, noise, and fuel consumption comparison of direct and indirect piezoelectric and solenoid injectors in a low-compression-ratio diesel engine. Energies. 2019, 4023(12). https://doi.org/10.3390/en12214023

[2] COSTA DE MACÊDO NETO, J., ANUNCIAÇÃO BRITO DE OLIVEIRA, M., BARREDA DEL CAMPO, E.R. at al. Failure in fuel injector nozzles used in diesel engines. Journal of Mechanics Engineering and Automation. 2015, 5, 237-240. https://doi.org/10.17265/2159-5275/2015.04.005

[3] CHOMIK, Z., ŁAGOWSKI, P. The analysis of mechanical damage of common rail injectors. Journal of Research and Applications in Agricultural Engineering. 2019, 64(1), 1320.

[4] CHOPRA, S., ACHARI, P., KULKARNI, V. Current market techniques used to reduce $\mathrm{CO}_{2}$ emissions from diesel engines. International Journal of Scientific Engineering and Applied Science. 2016, 2(12), 84-93.

[5] EGGER, K., WARGA, J., KLÜGL, W. New common rail injection system with piezo actuation for diesel passenger cars. MTZ Worldwide. 2002, 63(9), 14-17. https://doi.org/10.1007/BF03227566

[6] HAGEN, J., HERRMANN, O.E., WEBER, J. et al. Better diesel combustion by further injector improvement. Auto Tech Review. 2016, 5(9), 28-35. https://doi.org/10.1365/s40112-016-1198-4

[7] HAO, S., HUANG, Y., ZHANG, S. Research on the drive system of piezoelectric injector. Advances in Engineering Research. 2017, 100, 98-102.

https://doi.org/10.2991/icmeim-17.2017.19

[8] IGNACIUK, P., GIL, L. Damages to injectors in diesel engines. Advances in Science and Technology Research Journal. 2014, 21(8), 58-61. https://doi.org/10.12913/22998624.1091880

[9] JOCANOVIĆ, M.T., KARANOVIĆ, V.V., KNEŽEVIĆ, D.M. et al. Diesel fuel filtration problems with modern common rail injection systems. Vojnotehnićki Glasnik/ Military Technical Courier. 2017, 65(4), 968-933. https://doi.org/10.5937/vojtehg65-11577

[10] JUŚCIŃSKI, S., PIEKARSKI, W., CHOMIK, Z. Analysis of injection systems types used in agricultural machines. Agricultural Engineering. 2017, 21(4), 37-46. https://doi.org/10.1515/agriceng-2017-0034

[11] KACZOROWSKI, M., PILEWSKI, Z. Kodowanie IMA/ ISA wtryskiwaczy piezoelektrycznych. Bosch Autospec. 2017, 66(4), 7-9.

[12] KACZOROWSKI, M., PILEWSKI, Z. Wtryskiwacze piezoelektryczne - pionierzy wysokich ciśnień do 2500 barów. Bosch Autospec. 2017, 65(3), 7-10.

[13] KOTEN, H., GUNES, E.C., GUNER, K. Piezo-actuated common rail injector structure and efficient design. Journal of Energy Systems. 2018, 2(3), 97-114. https://doi.org/10.30521/jes.453560

[14] KRIVTSOV, S.N., KRIVTSOVA, T.I. Variations in health of piezoelectric elements of the Common Rail electric hydraulic nozzles in the operating conditions. IOP Conference Series: Materials Science and Engineering. 2021, 1061, 1-8. https://doi.org/10.1088/1757-899X/1061/1/012022

[15] MEGA TESTER V3. Software instruction manual version 3.0. The private company "Open System". 2019, Khmelnitsky.

[16] NOURAEI, H., BEN-MRAD, R., SINCLAIR, A.N. Development of a piezoelectric fuel injector. IEEE Transactions on Vehicular Technology. 2016, 65(3), 1162-1170. https://doi.org/10.1109/TVT.2015.2410136

[17] PAYRI, R., GIMENO, J., MATA, C. et al. Rate of injection measurements of a direct-acting piezoelectric injector for different operating temperatures. Energy Conversion and Management. 2017, 154, 387-393. https://doi.org/10.1016/j.enconman.2017.11.029

[18] POGULYAEV, Y.D., BAITIMEROV, R.M., ROZHDESTVENSKII, Y.V. Detailed dynamic modeling of common rail piezo injector. Procedia Engineering. 2015, 129, 93-98. https://doi.org/10.1016/j.proeng.2015.12.014 
[19] RAHUL, T.L. Recent trends in internal combustion engine. International Research Journal of Engineering and Technology. 2020, 7(4), 924-930.

[20] SALVADOR, F.J., PlaZAS, A.H., GIMENO, J. et al. Complete modelling of a piezo actuator last generation injector for diesel injection systems. International Journal of Engine Research. 2012, 15(1), 3-19. https://doi.org/10.1177/1468087412455373

[21] SATKOSKI, C.A., SHAVER, G.M., MORE, R. et al. Dynamic modeling of a piezoelectric actuated fuel injector. Proceedings of the 2009 IFAC Workshop on Engine and Powertrain Control, Simulation and Modeling IFP. 2009, 235-240. https://doi.org/10.3182/20091130-3-FR-4008.0048

[22] SENOUSY, M.S., LI, F.X., MUMFORD, D. et al. Thermoelectro-mechanical performance of piezoelectric stack actuators for fuel injector applications. Journal of Intelligent Material Systems and Structures. 2009, 20, 387-399. https://doi.org/10.1177/1045389X08095030

Tomasz Stoeck, DEng. - Faculty of Mechanical Engineering and Mechatronics, West Pomeranian University of Technology in Szczecin, Poland. e-mail: tstoeck@wp.pl
[23] STOECK, T. Application of the experimental design technique in fuel dose adjustment of common rail injector. Combustion Engines. 2019, 179(4), 210-215. https://doi.org/10.19206/CE-2019-435

[24] STOECK, T. Method for testing modern common rail piezoelectric fuel injectors. Combustion Engines. 2021, 186(3), 31-36. https://doi.org/10.19206/CE-140246

[25] STOECK, T. Methodology of testing common rail fuel injectors witch the use of Gauss`s formulas. Combustion Engines. 2021, 184(1), 11-15. https://doi.org/10.19206/CE-133505

[26] STOECK, T., ABRAMEK, K.F., OSIPOWICZ, T. Simplified methodology for testing common rail piezoelectric injectors taking into account reference characteristics. Engineering Review. 2021, 41(2), 54-61. https://doi.org/10.30765/er.1475 